\title{
What's in a Name?: Gender and the Generation of "Young Female Poets"
}

\author{
Sarah Holland-Batt
}

Queensland University of Technology

$\mathrm{L}$

ast year, at a lively town hall forum at James Cook University examining the question of gender bias in Australian literature, I was asked a question which astonished me. Did I, my interlocutor asked, personally feel "doubly marginalised as a female poet," due to poetry's marginal status in Australian literature, and women's marginal status as writers in general? My answer-with the caveat that I was speaking for myself-was an unequivocal no. Poetry undoubtedly occupies a peripheral position in Australian literary culture if column inches or literary festival stages are the measure of hitting the mainstream; as Ivor Indyk (2015) wrote recently in the Sydney Review of Books, "the prejudice against poetry goes deep" (para. 3) in Australia. Nevertheless, Australian poetry persists, and stubbornly flourishes. If the number of poems published annually is anything to go by, Australian poetry is positively burgeoning. Thousands of poems are published annually, alongside a Hydra-like sprouting of anthologies that shows no sign of slowing. There is a healthy stable of mostly small independent and university publishers who produce numerous individual volumes a year, alongside larger publishers such as Hachette, Scribe and Penguin and others who occasionally produce volumes by poet-novelists on their lists such as Cate Kennedy, Maxine Beneba Clarke and others. A healthy, albeit sometimes rancorous, debate about schools and modes of poetics accompanies these publications. A relatively large volume of reviews-if not, as Ben Etherington has noted, many especially critical ones-engages with these publications. From inside this maelstrom of activity, poetry hardly feels marginal.

In the midst of these clamouring voices, a purported "new generation of young female poets" has commanded particular attention from critics, and substantial representation on prize lists and in anthologies. Bronwyn Lea (2010) writes that "the most exciting poetry in Australia seems to be found, very often, in first books by young female poets" (p. 21), a consensus affirmed at times by critics as diverse as Geoff Page, John Tranter, Geoffrey Lehmann, Judith Beveridge, Julian Croft, among others. While there are not yet any current statistics focussed on the gender balance of reviews of the subcategory of Australian poetry, my overriding sense is that Australian poetry presently runs counter to trends that have prompted benchmarking projects examining gender balance in literature, such as the VIDA Count (http://www.vidaweb.org) in the United States and the Stella Count in Australia (http://thestellaprize.com.au). The rise of female poets is reflected in the two most recent anthologies surveying younger poets in Australia: Felicity Plunkett's anthology Thirty 
Australian Poets (2011), surveying poetry published since 1968, includes the work of eighteen women and twelve men; John Leonard's Young Poets: An Australian Anthology (2011) - while cleaving to a narrower lyrical brief -is also weighted towards women: five female poets and two male. At present, female Australian poets are hardly marginalised; if anything, they are in the ascendancy.

The notion of a new generation of young female poets was first articulated by Maria Takolander in an influential review of debut volumes by Elizabeth Campbell and L.K. Holt in Australian Book Review, both of which were early titles from publisher John Leonard Press. Commending both titles, Takolander (2008) asked, "Could it be time for young Australian women poets to shine? Are these two poets among the bright young things of a Generation of '08?' (p. 60). What began as a useful way of considering two distinctive poets whose work emerged from the same publisher at the same time took on new life during a heated debate on Pam Brown's now-concluded blog The Deletions (http://thedeletions.blogspot.com.au), where several poets and critics weighed in on the collective merits of the "ladies of the lyric," as one anonymous wag called them derisively en masse, and of the usefulness of grouping poets together by gender. Most of the female poets involved in the conversation on The Deletions indicated that they would prefer not to be, as Elizabeth Campbell (2009) put it, "lumped in with people who have analogous genitals, a date of birth within about the same decade as one's own, but whose work may be utterly different in style, intent and quality" (Brown $\mathrm{np}$ ). Yet, a decade later, some well-meaning critics still seem intent on repeatedly answering Takolander's initial questions in the affirmative, and about an ever-increasing cast of new female poets. The phrase "young female poets," or variants of it, recurs in reviews in The Australian, The Canberra Times, Australian Book Review, Poetry International, Westerly, and elsewhere. New volumes published by women are inevitably scrutinised in light of their female peers, irrespective of whether this is the most useful lens through which to contextualise their work, or not.

A by no means exhaustive list of poets most frequently mooted as part of this cohort includes Emma Jones, Elizabeth Campbell, Petra White, Bronwyn Lea, L.K. Holt, Bonny Cassidy, Kate Middleton, Fiona Wright, Judith Bishop, Jane Gibian, Michelle Cahill, Kathryn Lomer, Caitlin Maling, Felicity Plunkett, Chloe Wilson, Jessica Wilkinson, and more. It is significant to note that younger female Indigenous poets publishing lauded debut collections within the same timeframe-such as Ellen Van Neerven and Alison Whittaker-are not named by critics as part of this ever-expanding "generation," perhaps because, as Whittaker (2016) speculates, "Aboriginal women's writing is instead relegated to the halls of 'diversity writing'" (para. 7). Even a cursory glance at the works of the poets named by critics as belonging to this so-called "generation" refutes any notion of a unified school or aesthetic. Yet most younger female poets publishing their debuts since the initial brouhaha in 2009 have been added to this everincreasing roster when her work is reviewed, more evidence of what Geoffrey Lehmann praises as "an unprecedented constellation of fantastic young female poets in Australia" (as cited in Wilson, 2009. para. 25 ), or what Geoff Page (2014) enthusiastically calls "outstanding young (or youngish) Australian female poets who have emerged in the past decade" (p. 23), 
or "a whole new crop of outstanding young female Australian poets" (Page, 2015, p. 21). While most of the criticism is framed in such positive terms, the underlying inference of such categorisation is that women's writing is best understood in the context of other women's writing.

On the face of things, there is nothing inherently problematic about critics noting the preponderance of fine new books by women. Much of it is both well-intentioned and positive coverage, and given the dearth of criticism of works by women in forms other than poetry evident from successive Stella Counts, some may argue that a renewed interest in the category of "female poets" a good thing. It can be interesting to speculate about what has prompted the emergence of so many fine female poets in such a short span of time, or whatbeyond their shared sex-their works may have in common. Judith Beveridge (2009), examining the possible source of such an influx of fine debut volumes by women, thoughtfully speculates that these poets share "a confidence and maturity that earlier generations of female poets perhaps took longer to achieve, given the differences in societal and domestic circumstances, pressures and restraints" (p. 20). David McCooey (2007), seeking to draw broader connections than those established by gender, has proposed an emerging school of poetics, New Lyricism, that might gather several of the aforementioned young female poets together with some male counterparts under the shared interests of "worldliness, the uncanny and lyricism" (para. 25). Michelle Cahill (2011) has identified Younger New Formalism as a school wherein "a highly-wrought style ... resists conformity with traditional schools of lyric, [and] with adapted or experimental contemporary poetics" (p. 240). Geoff Page (2012), a prolific critic who has repeatedly expressed his admiration for the body of work produced by these young female poets, has suggested that their works are marked by metaphorical density, esotericism and recourse to mythology (p. 26)-descriptors broad enough that they might also encapsulate a spectrum of twentieth and twenty-first century male poets ranging from Geoffrey Hill to John Berryman, Derek Walcott, J.H. Prynne or Ted Hughes. Personally, I, like McCooey, suspect that any commonalities these poets have little to do with gender lines.

This brings me to a more pernickety semantic objection. As one of the writers who has been repeatedly cited as one of these so-called "young female poets," I have long baulked at the phrase. But why? Factually, it is accurate (or perhaps used to be when I was in my early twenties). But the phrase "young female poets" sounds diminishing to my ear. I am not sure when you cease, as a writer, to be "young." Is the cut-off eighteen, when you are able to buy liquor, or twenty-five, when, according to neuroscience, the frontal lobe is fully developed, or some other arbitrary point? Most of the poets above who have been repeatedly called "young female poets" are now well into their thirties and forties, and some case, fifties. I cannot think of a single male poet in those age brackets I have ever heard described as "young." Indeed, there is a good reason one doesn't read the descriptor "young male poet" much; when the poet is young and male, they are simply a "poet." T.S. Eliot was 23 years old by the time he had drafted "The Love Song of J. Alfred Prufrock"; when I re-read that poem, as I often do, I think of the poet as precocious, perhaps, but not "young." Likewise, Keats wrote his entire 
corpus by the age of 25 . In the popular imagination, Keats was a full-throated genius tragically cut off in his prime, not a "young male poet."

Setting aside the question of youth, the phrase "female poet" also carries connotations that generations of writers rejected for a reason. The contemporary push for gender parity in publishing-driven in part by statistic-gathering initiatives such as the VIDA and Stella Counts - has brought the question of visibility of women's writing in publishing to the fore, and increased awareness of disparities in publication numbers, but in doing so has also raised the spectre of biographical criticism that generations of female writers fought to repudiate. When Robert Lowell called Elizabeth Bishop one of the four best "women writ[ing] major poetry" in the United States in a 1971 interview, Bishop wrote a terse rejoinder to her erstwhile friend: "I'd rather be called 'the 16th poet' with no reference to my sex, than one of four womeneven if the other three are pretty good" (2008, p. 702). Bishop's reticence to be pigeonholed as a "woman writer" reflected a common sentiment among twentieth century women writers, and a distaste for biographical criticism cultivated by a critical culture intent on seeing women's writing through the lens of domesticity and gender, stretching all the way back to Hawthorne's pejorative denouncement of the "damned mob of scribbling women." For Bishop, being considered in the category of "female poets" or "women writers" diminished her, suggesting that her work belonged in a separate sphere to that of her male contemporaries. Unless the work itself invites a biographical reading or engages deeply with questions of gender, such an argument goes, the adjective "female" is neither necessary or illuminating. It goes without saying that contemporary female writers are working in a vastly different social and cultural landscape to that of Bishop, and that the phrase "female poet" has a less pejorative overtone than it once did. Indeed, I was fascinated to see John Kinsella (2017) observe-in a recent moving tribute to the late poet Fay Zwicky-that Zwicky wrote during "a time when poets in Australia were (honestly) divided as 'poets and women poets,' sometimes as a positive affirmation, but mostly by bloke poets and critics as a hierarchy" (para. 31); although much has changed since then, some of the nomenclature endures.

More broadly, though, such descriptors also reveal the way in which our conceptions of literature remain powerfully gendered. A male poet is a "poet"; a male novelist is a "novelist"; women undertaking the same activities, however, require a modifier. This phenomenon is not delimited to the arts; the news is replete with groundbreaking "female scientists" and "female mathematicians." Such linguistic habits-well-intentioned as they may be-reinforce the woman in such roles as the exception, rather than the norm. They also surely contribute to the results of a recent empirical study by Justin Levinson and Danielle Young (2010), which showed that when the majority of both male and female law students were asked to think of a judge, they thought of men: the noun without the modifier (p. 3); related thought experiments at Boston University similarly proved that when the majority of people are asked to think of a surgeon, they envisage men as well (Coontz, para. 5). These unconscious biases extend, of course, to notions of expertise and genius in literature. As Christine Battersby argued almost thirty years ago in her seminal Gender and Genius: Towards a Feminist Aesthetics, from the Romantic era onwards, notions of genius have been not only frequently framed to exclude 
women, but they have also drawn upon so-called "feminine" qualities: emotion, passion, sensitivity. A manifestation of these "feminine" attributes in the literary works of men is evidence of their transcendence of their nature, and hence their genius. In women, such qualities are perceived to be merely natural-indeed, at times, as weaknesses-and thus cannot elevate them to the category of genius. Even at the highest levels, the weighting towards a masculine conception of genius persists: in 2016, of the six Nobel Prize categories (economics, physiology or medicine, literature, peace, physics, and chemistry) not a single woman won. Since the awards' inception, 49 Nobel Prizes have been given to women, and 825 to men across those categories. While this disparity may have originally been attributable to the disparate educations offered to men and women, those days are well and truly on their way out, but the chasm remains.

Closer to home, it was such a scenario that prompted the naissance of the Stella Prize, when none of the shortlisted titles in either the 2009 or the 2011 Miles Franklin Prize were by women. Interestingly, in both years, there was a majority of female judges (three out of five) on the judging panel. In creating the Stella Prize, co-founder Sophie Cunningham noted, "reacted to the sense that things were slipping backwards in terms of the recognition of women's writing" (Neill, 2013, para.10). While the Stella-and similar prizes overseas such as the recentlyrenamed Baileys Women's Prize for Fiction-have copped criticism for the ghettoisation of women's fiction or for implying that it cannot compete with the works of men, they have also undoubtedly contributed to broader visibility of titles by women each year. With visibility comes sales, and with sales comes a greater longevity for a writer's career, further interest in future works, and so forth. So the Stella Prize has undoubtedly succeeded in its mission to bring writing by female Australian novelists, memoirists, and non-fiction writers to the fore (though not the works of female poets, who are ineligible for the prize). However, in her inaugural keynote, Helen Garner (2013) noted it would be preferable if the prize were not necessary, and if the biases that pervade publishing were vanquished rather than redressed:

How wonderful it would be if, one day, such a prize were no longer needed; if doctors and lawyers no longer said to me, "Pleased to meet you, Helen. My wife's read all your books"; if designers no longer reflexively put a picture of a vase of flowers or a teacup on a woman's book cover, even when the book is about hypodermics and vomiting and rage and the longing to murder. (Garner, 2013, para. 15)

Here, Garner puts her finger on the vexed issue of causation. Such imbalances have a nebulous and complex causative factors, from gendered marketing in the publishing sector to the attitudes of general readers to a woman's name on a book's spine, to women's sometimes unwillingness, as ex-Meanjin editor Zora Sanders (2014) has noted, to "take risks" and be bold when submitting their work for publication. Sanders observes anecdotally that "it's often remarked that a man will say yes to an assignment even if he's barely heard of the topic before, while women want to be experts before they agree to write on a topic" (para. 16); while the statisticians haven't yet compiled data examining the gender balance of submissions and pitches to publications, I suspect that those numbers might go some way towards elucidating the imbalance reflected in the finished product. A prize like the Stella can only do so much: bring a handful of books into renewed prominence, and, by extension, gesture to a broader 
body of work, but the truth is, as Sanders (2014) says, women must also "take risks" and put their work out there, pitching and risking being rejected in higher numbers in order for the balance to shift.

So: how to unpick the knot and arrive at a position about the question of gender bias in Australian literature? I think it is helpful to distinguish between two distinct but interrelated concerns. The first is the question of the visibility of works by women in the public domain, and the ways in which works by women are received, read, celebrated, and rewarded. This is being addressed, I suspect, both by initiatives such as the Stella Prize and other awards bringing greater visibility to works by women, but also by editors and journals who are trying behind the scenes to increase the number of female contributors. Data is helpful; the Stella Count has gone a long way to illuminate the lay of the land. The second, touchier question has to do with "women's writing" as a category, with all of the historical baggage such nomenclature entails, and whether such a category is helpful in the discussion about writing by women. Drawing attention to writing by women is a worthwhile endeavour, but calling writers "female poets" or "female novelists" or "female writers" as a kneejerk descriptor, in my view, is less helpful. If women writers choose to voluntarily describe themselves as "woman writers" or "female poets," or elect to appear in anthologies of feminist writing or women's literature, where the works are speaking to women's issues or from a feminist perspective, that is their prerogative. I myself have contributed to a couple over the years. To my mind, that is the appropriate context in which I would expect critics to consider writing by women as "women's writing": when gender is front and centre in the writing itself and the project of the book or publication. But I am concerned when I see the author's gender become the primary lens via which their writing is received and comprehended, in spite of its subject matter, as in the recent case of the "young female poets." These poets are rightfully being celebrated because they have written impressive books that contribute to the vibrant corpus of contemporary Australian literature. While it is important to bring such writing by women to the fore, let's give it the autonomy it deserves and just call it what it is: writing.

\section{References}

Battersby, C. (1989). Gender and genius: Towards a feminist aesthetics. Bloomington: Indiana UP.

Beveridge, J. (2009, October 7). Fine lines [Review of Letters to the Tremulous Hand by E. Campbell, Aria by S. Holland-Batt, The Striped World by E. Jones, and Vanishing Point by F. Plunkett]. The Australian. p. 20.

Brown, P. (2009, January 1). The Deletions. [Web log post]. Retrieved from http://thedeletions.blogspot.com

Cahill, M. (2011). [Review of Error by E. Campbell]. Southerly 71(3). 240-244.

Coontz, S. (2013, June 8). Progress at work, but mothers still pay a price. New York Times. Retrieved from http://www.nytimes.com

Garner, H. (2013, May 18) The losing game of writing books to win. The Australian. Retrieved from http://www.theaustralian.com.au

Indyk, I. (2015, March 20). On novelists and poets. Sydney Review of Books. Retrieved from 
http://sydneyreviewofbooks.com

Kinsella, J. (2017, July 22). Poet Fay Zwicky was a rebellious West Australian voice. The Australian. Retrieved from http://www.theaustralian.com.au

Lea, B. (2010). An assembly of poets. Westerly 55(1), 21-38.

Leonard, J. (Ed.). (2011). Young poets: An Australian anthology. St. Kilda, Vic: John Leonard Press

Levinson, J.D., \& Young, D. (2010). Implicit gender bias in the legal profession: An empirical study. Duke Journal of Gender Law \& Policy, 18(1), 1-41.

McCooey, D. (2007, May 1). Surviving Australian poetry: The new lyricism. Poetry International. Retrieved from http://www.poetryinternationalweb.net

Neill, R. (2013, April 6). A prize of one's own. The Australian. Retrieved from http://www.theaustralian.com.au

Page, G. (2012, Jan 28). Adventurous young'uns. The Canberra Times. p. 26.

Page, G. (2014, September 27). Love, actually [Review of $A$ Hunger by P. White, and Exhibits in the Sun by S. Edgar]. The Canberra Times. p. 23.

Page, G. (2015, August 29). New poetry: Robyn Rowland, Lucy Dougan, Sarah Holland-Batt [Review of This Intimate War Gallipoli/Çanakkale by R. Rowland, The Guardians by L. Dougan, and The Hazards by S. Holland-Batt]. The Australian. p. 29.

Plunkett, F. (Ed.). (2011). Thirty Australian poets. St Lucia: UQP.

Sanders, Z. (2014, July 2). Taking risks without an apology. Kill Your Darlings. Retrieved from https://www.killyourdarlings.com.au

Takolander, M. (2008). Generation of '08? Australian Book Review, 301, p. 60.

Travisano, T., \& Hamilton, S. (Eds.). (2008). Words in air: The complete correspondence between Elizabeth Bishop and Robert Lowell. London: Faber.

Wilson, P. (2009, November 28). Emma Jones: The genuine article. The Australian.Retrieved from http://www.theaustralian.com.au

Whittaker, A. (2016, February 3). On 'bad' poetry. Meanjin. Retrieved from https://meanjin.com.au 